\title{
STUDENT PERCEPTIONS OF FACE-TO-FACE AND ONLINE DISCUSSIONS: THE ADVANTAGE GOES TO ...
}

\author{
Dr. Katrina A. Meyer \\ Associate Professor of Higher and Adult Education \\ The University of Memphis
}

\begin{abstract}
Thirteen students in a graduate-level course on Historical and Policy Perspectives in Higher Education held face-to-face and online discussions on five controversial topics: Diversity, Academic Freedom, Political Tolerance, Affirmative Action, and Gender. Students read materials on each topic and generated questions for discussion that were categorized by Bloom's taxonomy so that the level of questions in the two discussion settings would be closely parallel. Upon completion of each discussion, they answered questions that addressed depth and length of the discussion, ability to remember, and a self-assessment of how the student learned. Students' assessments show a consistent preference for the face-to-face discussion but a small number of students preferred the online setting. However, what is perhaps more interesting is a minority of approximately one-third of the students who perceived no difference between the settings, or that the two settings were perhaps complementary.
\end{abstract}

\section{KEY WORDS}

Blended Learning, Face-to-Face and Online Discussions

\section{INTRODUCTION}

Within the past year, there has been increased interest in defining and studying the phenomenon of blended learning. Sloan-C has created a web site on blended learning (http://www.blendedteaching.org/) and published a compilation of research studies [1] (which includes an intriguing theoretical approach [2] for future research), and there have been other books and articles [3, 4, 5] on how to blend online and traditional methods appropriately and what may be the advantages and disadvantages of the format [6]. This interest is overdue, and indicates an interest on the part of faculty and researchers to identify what blended learning is and how to describe it, but more importantly, to determine how faculty can plan the face-to-face and online instructional components so that each works best for student learning.

But to be able to plan wisely for what works best in which part of the blended class, we need a better understanding of the differences_advantages as well as disadvantages — of face-to-face and online components of a program or course. Specifically, this research focuses on a narrow comparison of faceto-face and online discussions that have been designed to be closely similar in topic and level of "triggering questions" [7]. This was done to ensure that the study could be a more direct comparison of the two settings rather than inadvertently including too many variables that cannot be controlled or isolated such as when courses or programs are compared. 


\section{LITERATURE}

\section{A. Face-to-Face and Online Discussions}

Research on discussions held in the classroom has a long and fruitful history. Discussion has long been a favorite tool of instructors and understanding what works and what does not has depended on theories in psychology, sociology, and social psychology, among others. Research into small groups [8] stresses the complexity and adaptability of these groups as well as their dynamic qualities. It is important to see such groups as complex systems because complexity adds richness to the analysis of what occurs in a discussion, which depends on factors external to the group, relationships between or among group members, and internal psychological states of the individual members. Newer theories for studying group communication and discussions have been proposed, including functional, symbolic convergence, structuration, and feminist theories, cultural diversity perspectives, and dialectic theory [9]. Perhaps every theory that addresses the individual's psychology may be usefully applied to analyzing discussions. New approaches to studying classroom discussions include ethnographic studies [10] as well as mapping, charting, and diagramming activities, relationships, and content of contributions [11].

Research into online discussions has become an exploding field of endeavor. This may be due in large part because online discussions produce a written transcript, which can be analyzed using multiple approaches, and because they are widely used to encourage student-student and student-faculty interaction. Meyer [12] has reviewed the different purposes of analyzing online discussions, from faculty conducting research on theories of online learning to assessing student learning to an instructor wishing to learn how to better conduct online discussions and determine what improvements should be made for future classes. Useful theories for analyzing online discussions include the community of inquiry model [7], transactional distance [13], transactional theory [14], constructivist learning theory [15], computersupported cooperative work [16], collaborative learning [17,18], and online learning communities [19].

Many research studies compare face-to-face and online settings by using theories from face-to-face classrooms. Curtis and Lawson [20] applied characteristics of collaborative face-to-face learning to the study of online learning; Swan [21] explored the relationship of "verbal immediacy" in research on faceto-face communications to online communications; Picciano [22] explored the non-linear nature of asynchronous discussions which can branch into numerous "threads" rather than follow the more linear thread of face-to-face discussions; Meyer [23,24] applied theories from the pre-Internet world to analyze online communications. The next level of comparison one can find in the literature is when students are asked to compare online discussions held in class to previous face-to-face conversations which are not defined nor may be similar to the online discussions. Tiene [25] found that graduate students reacted positively to their online discussions, although they still preferred the face-to-face setting; these students noted that the online discussions were a valuable addition to the class and not a substitution for face-toface discussion. Meyer [26] and An and Frick [27] produced similar results when students compared their online discussions to their unspecified earlier experience with face-to-face discussions. The next level of comparison is when an online course is compared to a face-to-face one. This "comparison study" model may not be particularly well designed and has resulted in many "no significant difference" findings (see http://www.nosignificantdifference.org). Both Neuhauser [28] and Johnson et al. [29] compared face-toface and online courses and found no difference in student learning outcomes. On the other hand, Suthers et al. [30] focused more narrowly on comparing the roles of verbal and body gestures in collaboration in the two settings. Not surprisingly, face-to-face students used gestures to point to or indicate words or things under discussion. Online students were more likely to use words to do this and to focus on more recent material in the chatroom rather than all material available. In a comparison of online and blended learning, an interaction between the communication setting and type of task was found [31]. Sharing knowledge and coming to a joint solution was achieved better in a synchronous setting, and learners who 
worked together face-to-face and online had a more coherent experience. Results such as these confirm that it is not simply the setting that matters, but the match of task with the setting that influences learning.

What is missing in much of the research so far is a more direct comparison of face-to-face and online discussions. Based on earlier literature, what might we expect from such a comparison? Two intriguing possibilities can be found in the early work of Etzioni and Etzioni [32] and Hammond [33]. Hammond [33] concluded that there was a case to be made for multimodal learning including face-to-face mixed with asynchronous learning. Having said this, it is still not clear to the individual wanting to design good blended learning classes about what activities, content, or learning objectives would go best in which setting. Etzioni and Etzioni [32] concluded that "computer-mediated and face-to-face communities each have their own advantages as well as their own weaknesses.” In other words, we should be investigating what each setting can do that the other cannot, or cannot do as well. These writers seem to be implying that the two settings are different in some manner, and these differences may be complementary. These differences - and the nature of the differences—-need to be explored in greater detail.

\section{B. Blended Learning}

The interest in online discussions is perhaps the result of the rapid expansion of online learning. Enrollments in online courses in fall 2003 were 1.9 million students, having grown 20\% from fall 2002 [34], which grew by to 3.2 million students in Fall 2005 [35]. However, there is no current estimate of the number of students enrolled in blended courses, that is, courses that blend both face-to-face and online components. In fact, in recent research [35] estimating the penetration of blended learning courses and programs at U.S. higher education institutions, approximately $80 \%$ of public institutions offered at least one blended learning course, but the institutions could not identify how many courses were blended. In other words, administrators do not know how individual courses may be designed nor can they say how much blended learning is occurring at their institutions.

In order to provide some precision to the term of "blended learning," the Sloan-C Consortium adopted the following definition:

1. Courses that integrate online with traditional face-to-face class activities in a planned, pedagogically valuable manner; and

2. Where a portion (institutionally defined) of face-to-face time is replaced by online activity [37].

What is interesting about this definition is that it presumes that instructors will know which activities should be done in which setting (face-to-face or online), which activities may go best in which setting, and why. For discussions specifically, faculty need much better information about what differences exist between the two settings, or if no differences are discernable. This research is an attempt to directly compare the two discussion settings-face-to-face and online-using the perceptions of graduate students engaged in both types of discussions.

An earlier study [38] using the same methodology as in this study, asked graduate students to directly compare face-to-face and online discussions. In this research, students assessed their comfort, honesty, concern for others' feelings, similarity of feelings to others, and willingness to disagree and then compared the face-to-face and online discussions on these measures. Students indicated that some topics did elicit feelings of discomfort, concern for others' feelings, and lessened their willingness to disagree in the face-to-face discussions. However, despite these feelings, the majority of students continued to prefer the face-to-face discussions (which is similar to earlier findings [25, 26, 27]). Online discussions were 
valued to a lesser extent, but a consistent minority of students was more comfortable in that setting. The age and race of the student also created differences in responses, wherein older and African-American students appeared more comfortable with the controversial topics covered in the discussion. The current study will push the analysis further by asking different questions of a new group of graduate students as they complete parallel face-to-face and online discussions.

\section{Research Question}

This study was designed to address the general question, "Are there differences in student learning in face-to-face and online discussions?" The specific research question is "Do students perceive face-to-face and online discussions differently in terms of a) depth of learning, b) appropriate length for learning, c) ability to remember details and "who said what," d) where they learned more or better?" Answers to this question may help faculty determine when to schedule face-to-face discussions or online discussions and how to use the two discussion settings to achieve student learning for all.

\section{METHODOLOGY}

\section{A. Research Method}

In late summer 2005, approval was gained from the University of Memphis human subjects review board for this study. In fall 2006 during a graduate-level class on Historical and Policy Perspectives of Higher Education, the 13 enrolled students were asked to prepare for and participate in a series of discussions on controversial subjects in higher education. The controversial subjects were 1) Diversity, 2) Academic Freedom, 3) Political Tolerance, 4) Affirmative Action, and 5) Gender. These subjects were chosen because they are important policy issues in higher education and because students invariably have different views about them and a desire to discuss them in some depth. The instructor regularly modeled an open approach to discussions of controversial matter in the early weeks of the course; for example, the class tracked the changing definition of "diversity" in different historical eras in American higher education and analyzed data on the changing composition of higher education as regards class, race, and gender.

The instructor introduced the first of the controversial discussions in week six of a 15-week semester after having given the students several weeks to become familiar with the instructor and their fellow students. While the topics may have been controversial, the intent was not to make the discussions embarrassing or otherwise difficult for the students.

Students prepared for the discussions by reading four to five websites with research articles or data on the topic prior to coming to class for the face-to-face discussion. The topic of diversity focused on data about minorities in higher education as students, graduates, faculty, and institutional leaders. The discussion about academic freedom focused on the 1940 American Association of University Professors (AAUP) Statement on Academic Freedom, the Ward Churchill controversy, and articles on academic freedom after September $11^{\text {th }}$. The discussion about political tolerance focused on readings about the Student Bill of Rights and liberal and conservative points of view on higher education. The topic of affirmative action required a reading of the Michigan Supreme Court decisions and analyses of different approaches to college admissions not based on race. Lastly, the readings about gender focused on various issues affecting female students and faculty, including sexual harassment and family-friendly work policies.

Based on their readings, students developed questions they felt would be worthwhile discussing in class with their peers and wrote them on 4 × 6 note cards. This was done to maximize student interest in the 
discussion, and these questions were often better than those the instructor might have proposed. The instructor then categorized the questions into Bloom's taxonomy, recently updated by Anderson and Krathwohl [39]. These new categories reverse the two highest levels so that the taxonomy is (from lowest level to highest): know, understand, apply, analyze, evaluate, and create. Student questions were separated into two groups (for the two discussion settings), so that each group would include questions that required students to know, understand, apply, analyze, evaluate, or create. This was done in an attempt to make the two discussions as similar as possible in the level of questions asked although exact questions were clearly different. One group of questions was posed in class, one after another by the instructor; the other group of questions was posted online after the class was dismissed. In the face-toface setting, the discussion continued until exhausted, and then a new question was posed; in the online setting, four questions were posted by the instructor on the class WebCT Discussion Board and students were asked to post responses three to four times during the remainder of the week. The face-to-face discussion was held during class meeting times on Tuesday evenings, lasting one to two hours; the online discussion was held from Wednesday through the following Monday. Students' postings to the discussion board were not graded nor were points toward the final course grade given for their participation. The average number of postings across all discussions was 4.89 per student, well above the range requested by the instructor, and included all students in the class.

\section{B. Data Collection}

Data were gathered from these students at several times in the course. First, at the close of the face-to-face discussion, they were asked to complete a paper-and-pencil questionnaire containing six statements about a) the depth and comprehensiveness of the discussion, b) the length and use of resources in the discussion, c) the ability of the student to remember details and "who said what," and d) and a self-assessment of how the student learned "best" or "more." Answers were provided on a five-point Likert scale from very true = 1 , moderately true $=2$, somewhat true $=3$, a little true $=4$, not at all true $=5$. The instrument was limited to six items because prior experience indicated that the discussions can be exhausting and having better answers to fewer questions was more important than asking lots of questions.

Second, at the close of the online discussion, an online survey was available on Monday and Tuesday and asked each student the same questions using the same Likert scales as had been asked after the face-toface discussion (these data are displayed in Tables 1 through 5). Third, this online survey also asked them to compare the face-to-face and online discussion on the same measures (contained in Tables 6 through 10) and choose which discussion (face-to-face versus online) they preferred based on the statement. They also had an option of selecting "no difference." Fourth, Tables 11 through 16 reformat information in Tables 6 through 10 to better display comparisons across the discussions for each measure.

Lastly, to see if students' answers changed after the passage of time, a question on the course final exam asked the students to rank order the different discussion topics in terms of their value and to indicate for each topic whether they preferred the face-to-face or online discussion (Table 17), which eliminated the "no difference" option. The exam also asked two additional, open-ended questions: "Think about our classroom (face-to-face) and online discussions (in WebCT). Which mode (F2F or online) was deeper, better, more informative?" and "Which did you prefer, and why?" The analysis of the answers to the open-ended questions followed standard procedures for qualitative research [40] and identified themes, consistency in themes, and finally, exceptions to themes expressed by a minority of students. 


\section{Limitations}

The different survey questions capture the points of view of the students surveyed, who were in most cases older adult students and professionals in their field serving as administrators or staff within higher education institutions. In one sense, their responses may not be generalizable to other students in different courses. In another sense, these students are often reliable witnesses to their own learning processes. They are sufficiently mature so that when the discussion could and did become strained as opinions were expressed in a passionate fashion, respect for the principle of free exchange of ideas was confirmed. But it is essential to remember that these responses are only for 13 graduate students. Conclusions and interpretations must be tentative and discussed with caution.

The study depends upon the students being able to remember the face-to-face discussion, which would have occurred days earlier, in order to compare it to the online discussion for which they would have an online transcript of the discussion. Therefore, comparisons may be justifiably suspect. However, this problem plagues all research that depends on student memories, and must be considered as no worse or different than other research that asks students for their opinions of classes that have occurred over time.

The students' responses to the questionnaires are reported by mean, frequency, or percentage and are therefore largely descriptive. Given that responses did not produce a mound distribution, t-tests were not advisable; given the low number of students, chi-square tests were not possible because too many cells were less than five. Therefore, it is important to interpret the results as suggestive until the study can be replicated and expanded.

\section{RESULTS}

\section{A. Mean Responses After Each Discussion}

Tables 1 through 5 present the mean responses to the six Likert items after the students completed the face-to-face and online discussion. Occasionally, a student was unable to participate in a discussion, which is why sometimes the " $n$ " is less than 13. This is not a problem for the assessment of the discussions in Tables 1 through 5, but will affect the ability of students to compare discussions in Tables 6 through 10.

Because there is no way to assess the significance of the difference in these means, it is perhaps best to assume that means that are close to each other (say within two or three tenths) are "nearly equal" and those that are greater are deemed "not equal." These designations are captured in the final column as "nearly equal” or “ $\approx$ ” and "not equal” as “ $\neq$." This solution to determining differences is imprecise, but it recognizes that usual tests of statistical significance are inappropriate in this situation. In any case, of the 30 comparisons across all five discussions, only five items can be deemed "nearly equal" given these criteria.

Table 1: Mean Response for Diversity Discussions

Very true $=1$, Moderately true $=2$, Somewhat true $=3$, A little true $=4$, Not at all true $=5$

\begin{tabular}{|l|c|c|c|}
\hline \multicolumn{1}{|c|}{ Item } & $\begin{array}{c}\text { After F2F } \\
\text { Discussion } \\
(\mathbf{n = 1 3 )}\end{array}$ & $\begin{array}{c}\text { After Online } \\
\text { Discussion } \\
\mathbf{( n = 1 3 )}\end{array}$ & Difference \\
\hline $\begin{array}{l}\text { This discussion was in depth and } \\
\text { comprehensive. }\end{array}$ & 1.8 & 1.9 & $\approx$ \\
\hline
\end{tabular}




\begin{tabular}{|l|c|c|c|}
\hline $\begin{array}{l}\text { I remember details on the ideas in our } \\
\text { discussion. }\end{array}$ & 1.6 & 3.5 & $\neq$ \\
\hline $\begin{array}{l}\text { I thought we could have discussed } \\
\text { much longer and used more resources. }\end{array}$ & 1.9 & 2.0 & $\approx$ \\
\hline I learn more in this setting. & 1.9 & 3.7 & $\neq$ \\
\hline I learn better in this setting. & 1.5 & 3.6 & $\neq$ \\
\hline $\begin{array}{l}\text { I remember who said what in our } \\
\text { discussion. }\end{array}$ & 2.1 & 2.6 & $\neq$ \\
\hline
\end{tabular}

Table 2: Mean Response for Academic Freedom Discussions

Very true $=1$, Moderately true $=2$, Somewhat true $=3$, A little true $=4$, Not at all true $=5$

\begin{tabular}{|l|c|c|c|}
\hline \multicolumn{1}{|c|}{ Item } & \multicolumn{1}{|c|}{$\begin{array}{c}\text { After F2F } \\
\text { Discussion } \\
\mathbf{( n = 1 2 )}\end{array}$} & $\begin{array}{c}\text { After Online } \\
\text { Discussion } \\
\mathbf{( n = 1 3 )}\end{array}$ & Difference \\
\hline $\begin{array}{l}\text { This discussion was in depth and } \\
\text { comprehensive. }\end{array}$ & 1.5 & 1.8 & $\approx$ \\
\hline $\begin{array}{l}\text { I remember details on the ideas in our } \\
\text { discussion. }\end{array}$ & 1.8 & 3.0 & $\neq$ \\
\hline $\begin{array}{l}\text { I thought we could have discussed } \\
\text { much longer and used more resources. }\end{array}$ & 2.8 & 3.4 & $\neq$ \\
\hline I learn more in this setting. & 1.9 & 3.8 & $\neq$ \\
\hline I learn better in this setting. & 1.8 & 3.2 & $\neq$ \\
\hline $\begin{array}{l}\text { I remember who said what in our } \\
\text { discussion. }\end{array}$ & 1.8 & & $\neq$ \\
\hline
\end{tabular}

Table 3: Mean Response for Political Tolerance Discussions

Very true $=1$, Moderately true $=2$, Somewhat true $=3$, A little true $=4$, Not at all true $=5$

\begin{tabular}{|l|c|c|c|}
\hline \multicolumn{1}{|c|}{ Item } & \multicolumn{1}{|c|}{$\begin{array}{c}\text { After F2F } \\
\text { Discussion } \\
(\mathbf{n = 1 2 )}\end{array}$} & $\begin{array}{c}\text { After Online } \\
\text { Discussion } \\
\mathbf{( n = 1 3 )}\end{array}$ & Difference \\
\hline $\begin{array}{l}\text { This discussion was in depth and } \\
\text { comprehensive. }\end{array}$ & 1.3 & 2.4 & $\neq$ \\
\hline $\begin{array}{l}\text { I remember details on the ideas in our } \\
\text { discussion. }\end{array}$ & 1.6 & 3.2 & $\neq$ \\
\hline $\begin{array}{l}\text { I thought we could have discussed } \\
\text { much longer and used more } \\
\text { resources. }\end{array}$ & 3.3 & 3.3 & $\neq$ \\
\hline I learn more in this setting. & 2.0 & 3.8 & $\neq$ \\
\hline I learn better in this setting. & 2.6 & 3.0 & $\neq$ \\
\hline $\begin{array}{l}\text { I remember who said what in our } \\
\text { discussion. }\end{array}$ & 2.0 & & $\neq$ \\
\hline
\end{tabular}


Table 4: Mean Response for Affirmative Action Discussions

Very true $=1$, Moderately true $=2$, Somewhat true $=3$, A little true $=4$, Not at all true $=5$

\begin{tabular}{|l|c|c|c|}
\hline \multicolumn{1}{|c|}{ Item } & \multicolumn{1}{|c|}{$\begin{array}{c}\text { After F2F } \\
\text { Discussion } \\
(\mathbf{n = 1 2 )}\end{array}$} & $\begin{array}{c}\text { After Online } \\
\text { Discussion } \\
\mathbf{( n = 1 3 )}\end{array}$ & Difference \\
\hline $\begin{array}{l}\text { This discussion was in depth and } \\
\text { comprehensive. }\end{array}$ & 2.1 & 3.0 & $\neq$ \\
\hline $\begin{array}{l}\text { I remember details on the ideas in our } \\
\text { discussion. }\end{array}$ & 1.7 & 2.5 & $\approx$ \\
\hline $\begin{array}{l}\text { I thought we could have discussed } \\
\text { much longer and used more } \\
\text { resources. }\end{array}$ & 2.2 & 3.5 & $\neq$ \\
\hline I learn more in this setting. & 2.1 & 3.8 & $\neq$ \\
\hline I learn better in this setting. & 1.8 & 2.9 & $\neq$ \\
\hline $\begin{array}{l}\text { I remember who said what in our } \\
\text { discussion. }\end{array}$ & 1.8 & & $\neq$ \\
\hline
\end{tabular}

Table 5: Mean Response for Gender Discussions

Very true $=1$, Moderately true $=2$, Somewhat true $=3$, A little true $=4$, Not at all true $=5$

\begin{tabular}{|l|c|c|c|}
\hline \multicolumn{1}{|c|}{ Item } & \multicolumn{1}{|c|}{$\begin{array}{c}\text { After F2F } \\
\text { Discussion } \\
(\mathbf{n = 1 0 )}\end{array}$} & $\begin{array}{c}\text { After Online } \\
\text { Discussion } \\
(\mathbf{n = 1 2 )}\end{array}$ & Difference \\
\hline $\begin{array}{l}\text { This discussion was in depth and } \\
\text { comprehensive. }\end{array}$ & 1.4 & 2.3 & $\neq$ \\
\hline $\begin{array}{l}\text { I remember details on the ideas in our } \\
\text { discussion. }\end{array}$ & 1.7 & 2.4 & $\approx$ \\
\hline $\begin{array}{l}\text { I thought we could have discussed } \\
\text { much longer and used more } \\
\text { resources. }\end{array}$ & 3.0 & 3.0 & $\neq$ \\
\hline I learn more in this setting. & 1.9 & 3.5 & $\neq$ \\
\hline I learn better in this setting. & 1.7 & 2.6 & $\neq$ \\
\hline $\begin{array}{l}\text { I remember who said what in our } \\
\text { discussion. }\end{array}$ & & 2.9 & $\neq$ \\
\hline
\end{tabular}

\section{B. Preference for Discussion Setting by Likert Item}

Tables 6 through 10 capture the students' comparisons of the two discussions, one held face-to-face and the other online. They were asked to choose which discussion they preferred or indicate "no difference," so the numbers in these tables represent a simple frequency of "votes" for that setting. Tables 1 through 5 present a picture of clear advantage for the face-to-face setting, which received the majority of votes in each discussion, ranging from $33 \%$ to $54 \%$ for a total average of all votes cast of $43 \%$. The online discussions received a minority of votes as the preferred setting for the discussions, receiving a total average of all votes cast of $20 \%$. But what is perhaps most intriguing are the votes of "no difference," which increase across the discussions, from 24 in the first discussion, 29 in the second, 25 in the third, 33 in the fourth, 27 in the fifth for a total of all votes cast of over a third (35\%) of the students in the class. 
Table 6: Comparison of Diversity Discussions ( $n=13)$

\begin{tabular}{|l|c|c|c|}
\hline \multicolumn{1}{|c|}{ Item } & F2F & Online & No Difference \\
\hline $\begin{array}{l}\text { This discussion was in depth and } \\
\text { comprehensive. }\end{array}$ & 4 & 8 & 1 \\
\hline $\begin{array}{l}\text { I remember details on the ideas in our } \\
\text { discussion. }\end{array}$ & 7 & 1 & 2 \\
\hline $\begin{array}{l}\text { I thought we could have discussed } \\
\text { much longer and used more } \\
\text { resources. }\end{array}$ & 5 & 2 & 7 \\
\hline I learn more in this setting. & 7 & 2 & 4 \\
\hline I learn better in this setting. & 8 & 0 & 7 \\
\hline $\begin{array}{l}\text { I remember who said what in our } \\
\text { discussion. }\end{array}$ & 6 & 17 & 24 \\
\hline Total votes & $42 \%$ & $24 \%$ & $34 \%$ \\
\hline Percent of total votes cast & & 4 & 7 \\
\hline
\end{tabular}

Table 7: Comparison of Academic Freedom Discussions (n=12)

\begin{tabular}{|l|c|c|c|}
\hline \multicolumn{1}{|c|}{ Item } & F2F & Online & No Difference \\
\hline $\begin{array}{l}\text { This discussion was in depth and } \\
\text { comprehensive. }\end{array}$ & 6 & 4 & 2 \\
\hline $\begin{array}{l}\text { I remember details on the ideas in our } \\
\text { discussion. }\end{array}$ & 5 & 3 & 5 \\
\hline $\begin{array}{l}\text { I thought we could have discussed } \\
\text { much longer and used more } \\
\text { resources. }\end{array}$ & 3 & 1 & 6 \\
\hline I learn more in this setting. & 8 & 3 & 2 \\
\hline I learn better in this setting. & 7 & 0 & 9 \\
\hline $\begin{array}{l}\text { I remember who said what in our } \\
\text { discussion. }\end{array}$ & 32 & 13 & 27 \\
\hline Total votes & $44 \%$ & $18 \%$ & $38 \%$ \\
\hline Percent of total votes cast & 32 & 2 & 3 \\
\hline
\end{tabular}

Table 8: Comparison of Political Tolerance Discussions (n=12)

\begin{tabular}{|l|c|c|c|}
\hline \multicolumn{1}{|c|}{ Item } & F2F & Online & No Difference \\
\hline $\begin{array}{l}\text { This discussion was in depth and } \\
\text { comprehensive. }\end{array}$ & 7 & 3 & 2 \\
\hline $\begin{array}{l}\text { I remember details on the ideas in our } \\
\text { discussion. }\end{array}$ & 6 & 2 & 4 \\
\hline $\begin{array}{l}\text { I thought we could have discussed } \\
\text { much longer and used more } \\
\text { resources. }\end{array}$ & 3 & 1 & 8 \\
\hline I learn more in this setting. & 9 & 2 & 1 \\
\hline I learn better in this setting. & 10 & 0 & 2 \\
\hline
\end{tabular}


Student Perceptions of Face-to-Face and Online Discussions: The Advantage Goes To . . .

\begin{tabular}{|l|c|c|c|}
\hline $\begin{array}{l}\text { I remember who said what in our } \\
\text { discussion. }\end{array}$ & 4 & 0 & 8 \\
\hline Total votes & 39 & 8 & 25 \\
\hline Percent of total votes cast & $54 \%$ & $11 \%$ & $35 \%$ \\
\hline
\end{tabular}

Table 9: Comparison of Affirmative Action Discussions (n=12)

\begin{tabular}{|l|c|c|c|}
\hline \multicolumn{1}{|c|}{ Item } & F2F & Online & No Difference \\
\hline $\begin{array}{l}\text { This discussion was in depth and } \\
\text { comprehensive. }\end{array}$ & 5 & 5 & 2 \\
\hline $\begin{array}{l}\text { I remember details on the ideas in our } \\
\text { discussion. }\end{array}$ & 5 & 2 & 5 \\
\hline $\begin{array}{l}\text { I thought we could have discussed } \\
\text { much longer and used more } \\
\text { resources. }\end{array}$ & 2 & 2 & 3 \\
\hline I learn more in this setting. & 7 & 1 & 3 \\
\hline I learn better in this setting. & 4 & 0 & 8 \\
\hline $\begin{array}{l}\text { I remember who said what in our } \\
\text { discussion. }\end{array}$ & 31 & 12 & 29 \\
\hline Total votes & $43 \%$ & $17 \%$ & $40 \%$ \\
\hline Percent of total votes cast & 4 & 2 & 8 \\
\hline
\end{tabular}

Table 10: Comparison of Gender Discussions (n=12)

\begin{tabular}{|l|c|c|c|}
\hline \multicolumn{1}{|c|}{ Item } & F2F & Online & No Difference \\
\hline $\begin{array}{l}\text { This discussion was in depth and } \\
\text { comprehensive. }\end{array}$ & 2 & 4 & 6 \\
\hline $\begin{array}{l}\text { I remember details on the ideas in our } \\
\text { discussion. }\end{array}$ & 3 & 3 & 4 \\
\hline $\begin{array}{l}\text { I thought we could have discussed } \\
\text { much longer and used more } \\
\text { resources. }\end{array}$ & 2 & 2 & 7 \\
\hline I learn more in this setting. & 8 & 3 & 2 \\
\hline I learn better in this setting. & 7 & 2 & 8 \\
\hline $\begin{array}{l}\text { I remember who said what in our } \\
\text { discussion. }\end{array}$ & 2 & 19 & 29 \\
\hline Total votes & $33 \%$ & $26 \%$ & $40 \%$ \\
\hline Percent of total votes cast & 24 & 3 & 2 \\
\hline
\end{tabular}

\section{Preference for Setting across Discussions}

Tables 11 through 16 reformat the information in Tables 6 through 10 to place the emphasis on the measure or Likert item across the five discussions. These displays make certain relationships clearer. First, the students gave an equal number of "votes" to each setting, implying that they felt the depth of the discussions were equivalent (Table 11). Second, there is a slight advantage to face-to-face discussions for remembering details and a much larger advantage for face-to-face discussions for remembering "who said 
what” (Tables 12 and 16). Third, it is clear that these students felt they learned more and better in face-toface discussions (Tables 14 and 15). Lastly, this formatting makes it clear that the largest percent of votes are for "no difference" on two measures: "could have discussed longer and used more resources" as well as remembering "who said what" (Tables 13 and 16). This last difference may be due to the fact that the online discussion occurred over one week and the face-to-face discussion for one to two hours, but since discussions in these settings are invariably of different lengths, the shortness of the face-to-face discussion may be a limit and the unlimited nature of online discussions an advantage.

Table 11: Student Preference for Setting Based on Depth of Discussion

\begin{tabular}{|l|c|c|c|}
\hline \multicolumn{1}{|c|}{ Discussions } & F2F & Online & No Difference \\
\hline Diversity & 4 & 8 & 1 \\
\hline Academic Freedom & 6 & 4 & 2 \\
\hline Political Tolerance & 7 & 3 & 2 \\
\hline Affirmative Action & 5 & 5 & 2 \\
\hline Gender & 2 & 4 & 6 \\
\hline Total votes & 24 & 24 & 13 \\
\hline Percent of total votes cast & $39 \%$ & $39 \%$ & $21 \%$ \\
\hline
\end{tabular}

Table 12: Student Preference for Setting Based on Remembering Details

\begin{tabular}{|l|c|c|c|}
\hline Discussions & F2F & Online & No Difference \\
\hline Diversity & 7 & 4 & 2 \\
\hline Academic Freedom & 5 & 2 & 5 \\
\hline Political Tolerance & 6 & 2 & 4 \\
\hline Affirmative Action & 5 & 2 & 5 \\
\hline Gender & 3 & 5 & 4 \\
\hline Total votes & 26 & 15 & 20 \\
\hline Percent of total votes cast & $43 \%$ & $25 \%$ & $33 \%$ \\
\hline
\end{tabular}

Table 13 :Student Preference for Setting Based on Could Have Discussed Longer and Use More Resources

\begin{tabular}{|l|c|c|c|}
\hline \multicolumn{1}{|c|}{ Discussions } & F2F & Online & No Difference \\
\hline Diversity & 5 & 1 & 7 \\
\hline Academic Freedom & 3 & 3 & 6 \\
\hline Political Tolerance & 3 & 1 & 8 \\
\hline Affirmative Action & 2 & 2 & 8 \\
\hline Gender & 2 & 3 & 7 \\
\hline Total votes & 15 & 10 & 36 \\
\hline Percent of total votes cast & $25 \%$ & $16 \%$ & $59 \%$ \\
\hline
\end{tabular}

Table 14: Student Preference for Setting Based on Learn More in Setting

\begin{tabular}{|l|c|c|c|}
\hline \multicolumn{1}{|c|}{ Discussions } & F2F & Online & No Difference \\
\hline Diversity & 7 & 2 & 4 \\
\hline Academic Freedom & 8 & 1 & 3 \\
\hline
\end{tabular}


Student Perceptions of Face-to-Face and Online Discussions: The Advantage Goes To . . .

\begin{tabular}{|l|c|c|c|}
\hline Political Tolerance & 9 & 2 & 1 \\
\hline Affirmative Action & 7 & 2 & 3 \\
\hline Gender & 8 & 2 & 2 \\
\hline Total votes & 39 & 9 & 13 \\
\hline Percent of total votes cast & $64 \%$ & $15 \%$ & $21 \%$ \\
\hline
\end{tabular}

Table 15: Student Preference for Setting Based on Learn Better in Setting

\begin{tabular}{|l|c|c|c|}
\hline \multicolumn{1}{|c|}{ Discussions } & F2F & Online & No Difference \\
\hline Diversity & 8 & 2 & 3 \\
\hline Academic Freedom & 7 & 3 & 2 \\
\hline Political Tolerance & 10 & 0 & 2 \\
\hline Affirmative Action & 8 & 1 & 3 \\
\hline Gender & 7 & 3 & 2 \\
\hline Total votes & 40 & 9 & 12 \\
\hline Percent of total votes cast & $66 \%$ & $15 \%$ & $20 \%$ \\
\hline
\end{tabular}

Table 16: Student Preference for Setting Based on Remembering Who Said What

\begin{tabular}{|l|c|c|c|}
\hline \multicolumn{1}{|c|}{ Discussions } & F2F & Online & No Difference \\
\hline Diversity & 6 & 0 & 7 \\
\hline Academic Freedom & 3 & 0 & 9 \\
\hline Political Tolerance & 4 & 0 & 8 \\
\hline Affirmative Action & 4 & 0 & 8 \\
\hline Gender & 2 & 2 & 8 \\
\hline Total votes & 19 & 2 & 40 \\
\hline Percent of total votes cast & $31 \%$ & $3 \%$ & $66 \%$ \\
\hline
\end{tabular}

\section{Rank Order of Discussions}

Approximately 3 weeks after the last discussion, a take-home final exam was given. As part of the exam, students were asked to reflect on the two types of discussions across the five topics and rank order their preference for the topics and then choose which mode or setting worked best for them. Table 17 presents the mean rank and their choices for best setting. The online discussions were deemed "best" by more students than one might expect by viewing Tables 6 through 14. This may be due to forcing students to choose a "best” setting (they weren't given the option of choosing "no difference” in this request), but it may also capture a real difference. Perhaps students had a better experience with the online discussion than originally thought.

Table 17: Rank Order of Discussions and "Best" Setting at Final Exam

\begin{tabular}{|l|c|c|c|}
\hline \multicolumn{1}{|c|}{ Topic } & Mean Rank & F2F Best & Online Best \\
\hline Diversity & 1.75 & 5 & 7 \\
\hline Academic Freedom & 3.17 & 8 & 3 \\
\hline Political Tolerance & 2.92 & 8 & 4 \\
\hline
\end{tabular}


Student Perceptions of Face-to-Face and Online Discussions: The Advantage Goes To ...

\begin{tabular}{|l|c|c|c|}
\hline Affirmative Action & 3.08 & 6 & 6 \\
\hline Gender & 3.42 & 9 & 3 \\
\hline Total votes & & 36 & 23 \\
\hline Percent of total votes cast & & $61 \%$ & $39 \%$ \\
\cline { 2 - 4 }
\end{tabular}

\section{E. Responses to Open-Ended Question, “Why?”}

At the end of the final exam, students were asked two open-ended questions asking them to (1) discuss which mode (face-to-face or online) of discussion was deeper, better, and more informative, and (2) then discuss which mode they personally preferred. The answers reflect three themes: (1) advantages of faceto-face discussion, (2) advantages of online discussion, (3) and the complementarity of the two settings.

The advantages of face-to-face discussion can be captured by three sub-themes. The first sub-theme, and the one mentioned most frequently by students, was the emotion, energy, fluidity, and ease of face-to-face exchanges. These descriptors capture very real advantages that most people enjoy about face-to-face exchanges. Another sub-theme that captures reasons for giving the advantage to face-to-face discussions was the ability to read nonverbal signs (body language, facial expressions), which seemed very important to some students. While the last sub-theme had only two mentions, it is perhaps the most insightful: with immediate feedback (through nonverbal cues or verbal responses from their classmates), the students' points-of-view are immediately evaluated and in a way that is "often more memorable," said one student. Another student put the issue in this way, "It is easier to respond and react in the face-to-face discussion. You can more easily defend your responses and change your perspective too.” This may support the advantage of face-to-face exchanges for assessing the success of your argument with your classmatestheir frowns are ample feedback - as well as their advantage for remembering details in a discussion and "who said what" as captured in Tables 12 and 16. This comment also raises a question that cannot be resolved by the current study, whether changing one's point of view occurs in the face-to-face setting because confrontation (or questioning another's reasoning) is more effective in the face-to-face setting; this also makes one wonder if the lack of face-to-face confrontation in strictly online learning might lead to the fewer changes in the point-of-view of students.

The advantages of online discussion can be captured by three sub-themes. The first sub-theme is wellestablished in the research literature on online discussions: the ability to take the time and care to reflect on what response should be made, or as one student put it, "I can express myself better when I can think about what I want to say." And another wrote, "Working from home and having more time to think and reflect before responding yielded deeper and better thought-out postings.” The second sub-theme refers to the online discussions being more reasoned, providing more information, and perhaps deeper analysis. "Oral responses are sometimes instinctive rather than reasoned," noted one student. Or as another student who expressed a preference for the face-to-face setting indicated, "I like to ... hear passion ... I want to voice [my] opinion. If I have to type my response, I tend to be less vocal, opinionated, passionate." Another student wrote, "I preferred online . . . because I had to really think and write my comments in a way as not to offend ... when you are talking about issues, it is so easy to get caught up in your passions that you may come across as offensive, narrow-minded, or prejudiced." These latter two comments indicate that the two settings may be complementary: face-to-face stirs and is more suitable for the expression of passion, but the online environment tends to temper the passions, cools them perhaps, or forces them into the linear, rational world of written prose. The last sub-theme, noted by several students, was the opportunity for the quieter students to open up online. 
Lastly, one student identified the importance of "blending" both types of discussions: "Both environments have limit[s]... so one is not necessarily better than the other, but different." If the two settings are complementary - as the comments about expressing passion versus expressing thoughts in a more rational manner above imply - then the issue is how faculty can use this finding in ways to enhance learning for all in a blended learning approach. If the two modes of discussion-face-to-face and onlineare different, how can instructors ensure that discussions in the different settings complement each other and maximize learning for students with different strengths and weaknesses and different preferences for the energy of face-to-face meetings or for the time to reflect in the online setting? This means that the issue may not be which setting has an advantage-both do-but how to thoughtfully design instruction so as to capitalize on the complementary aspects of the settings in ways that draw on the strengths of all students and help all students address their weaknesses.

\section{DISCUSSION}

This research cannot be definitive, but it is suggestive of a number of interesting insights into how these students perceived face-to-face and online discussions in a blended learning context. First, when it comes to the depth and comprehensiveness of a discussion, the face-to-face and online settings were rather equivalent. Although one might expect that depth and comprehensiveness might be an obvious advantage of the online setting, it did not hold true in the eyes of these students.

Second, another advantage for the online setting in the literature is its ability to expand the time and resources available for an educational objective [26]. However in this study, the majority of students indicated no difference between the settings on this measure, so perhaps this is a "draw" when comparing the two settings.

Third, remembering details and "who said what" seem to be better in the face-to-face setting for these students. This is intriguing, since the script of the online discussions would have been available to them to help remember and they might have just completed reading the last postings to the discussion prior to taking the survey. So perhaps this question does capture an important difference: face-to-face discussions allow students to capture the feel, tone, and emotion of an exchange that helps memories to form and be remembered.

Fourth, when asked to distinguish between the settings in their ability to support learning - either learning more or better - a clear majority of students prefer the face-to-face discussions as was found by others $[25,26,27]$. A minority prefer the online discussion and another minority express no preference. And as an aside to future researchers, these students did not rate "learn more" much differently than "learn better." The differences in scores for each discussion ranged from no difference to seven-tenths of a difference. Perhaps in the future, one or the other term would serve the researcher as well as trying to determine differences that students have difficulty distinguishing.

Fifth, what may be most intriguing in these comparisons is the large number of times the students chose "no difference" between the settings. Perhaps this is a sign that at least one-third of students find the two settings equitable. This may bode well for some day putting to rest the need to compare the settings in order to justify using online discussions in instruction.

Sixth, although the students seem to have firm preferences for one setting, the reasons for their preference are in some ways complementary: passion versus reason, energy versus time, instinctual versus reflection. Another way this may be characterized is that both settings present communication barriers for different 
students; therefore, blended learning levels the playing field and encourages even participation [41]. These insights into the complementarity of the two discussion settings argue for a better understanding into how each setting could complement the other in a course, allowing some students to enjoy the energy and flow of face-to-face discussions but others to shine in their well-thought-out online postings.

Seventh, the issue in front of instructors is how to translate student preferences into a well-designed instructional experience. How should the complementarity of the two settings be incorporated into a blended learning course? These findings encourage instructors to use both types of discussions, perhaps stressing questions that encourage energetic exploration in the face-to-face setting, but developing questions or issues that require thoughtful and rational resolutions in the online setting. Brainstorming ideas may work better in the face-to-face setting, but analyzing and evaluating those ideas will be better in the online setting. And while challenging student thinking must occur whenever it is appropriate, perhaps it is more effective in the face-to-face setting. The instructor would be wise to take into consideration the characteristics of each discussion setting when deciding upon the nature of the learning task or the charge to the discussants.

Lastly, the need for more and better research into understanding the specific advantages and disadvantages of the two components of blended learning is obvious. This particular research study cannot resolve the question of when to use face-to-face discussion or what topic may work best in the online setting or whether there are any differences at all. But it captures, in a small group of graduate students, how discussions may need to be done in both settings so that students can enjoy the advantages of the particular setting. One final insight worth further explication is whether what these students saw as "equivalent" or "not different" is accurate, or whether the settings are complementary in ways that researchers must investigate and instructors need to explore.

In a final analysis, students seem to feel that in a comparison of face-to-face and online discussions, the advantage goes to . . . both. There are positive characteristics of each setting for a discussion and negative ones as well. But what may be most intriguing is how the differences in the two settings may be useful for encouraging different types of learning experiences that are valuable . . . both of them.

\section{REFERENCES}

1. Picciano, A. G. and C. D. Dziuban. (Eds.) Blended Learning: Research Perspectives. Needham, MA: Sloan Consortium, 2007.

2. Shea, $\mathbf{P}$. Towards a conceptual framework for learning in blended environments. In A. G. Picciano and C. D. Dziuban (Eds.), Blended Learning: Research Perspectives, 19-35. Needham, MA: Sloan Consortium, 2007.

3. Bonk, C. J., and C. R. Graham. The Handbook of Blended Learning: Global Perspectives, Local Designs. New York: Pfeiffer, 2005.

4. Thorne, K. Blended Learning: How to Integrate Online and Traditional Learning. Sterling, VA: Kogan Page, 2003.

5. Vaughan, N. Perspectives on blended learning in higher education. International Journal on ELearning 6(1): 81-94, 2007.

6. Graham, C. R. Blended learning systems: Definition, current trends, and future directions. In C. J. Bonk and C. R. Graham (Eds.), The Handbook of Blended Learning: Global Perspectives, Local Designs, 3-21. New York: Pfeiffer, 2005.

7. Garrison, D. R., T. Anderson and W. Archer. Critical thinking, cognitive presence, and computer conferencing in distance education. The American Journal of Distance Education 15(1): 7-23, 2001. 
8. Arrow, H., J. E. McGrath and J. L. Berdahl. Small Groups as Complex Systems. New York: Sage Publications, 2000.

9. Frey, L. R. (Ed.) New Directions in Group Communication. Thousand Oaks, CA: Sage Publications, 2002.

10. Wyatt, N. Methodological procedures: Ethnographic practices in group communication research. In L. R. Frey (Ed.), New Directions in Group Communication. Thousand Oaks, CA: Sage Publications, 2002.

11. Gulley, H. E. Discussion, Conference and Group Process. New York: Holt, Rinehart \& Winston, Inc., 1968.

12. Meyer, K. A. The method (and madness) of evaluating online discussions. Journal of Asynchronous Learning Networks 10(4): 83-97, 2006. http://www.sloan-c.org/publications/jaln/v10n4/pdf /v10n4_meyer1.pdf.

13. Moore, M. G. Three types of interaction. In K. Harry, M. John and D. Keegan (Eds.), Distance Education: New Perspectives, 19-24. New York: Routledge, 1993.

14. Garrison, R. Theoretical challenges for distance education in the $21^{\text {st }}$ century: A shift from structural to transactional issues. International Review of Research in Open and Distance Learning 1(1): 2000. http://www.irrodl.org/index.php/irrodl/article/view/2/333.

15. Gunawardena, C. N., C. A. Lowe and T. A. Anderson. Analysis of a global online debate and the development of an interaction analysis model for examining social construction of knowledge in computer conferencing. Journal of Educational Computing Research 17(4): 397-431, 1997.

16. Newman, D. R., B. Webb and C. Cochrane. A content analysis method to measure critical thinking in face-to-face and computer supported group learning. Interpersonal Computing and Technology 3(2): 56-77, 1995.

17. Aviv, R. Educational performance of ALN via content analysis. Journal of Asynchronous Learning Networks 4(2): 53-72, 2000.

18. Aviv, R., Z. Erlich, G. Ravid and A. Geva. Network analysis of knowledge construction in asynchronous learning networks. Journal of Asynchronous Learning Networks 7(3): 1-23, 2003.

19. Brown, R. E. The process of community-building in distance learning classes. Journal of Asynchronous Learning Networks 5(2): 2001.

20. Curtis, D. D. and M. J. Lawson. Exploring collaborative online learning. Journal of Asynchronous Learning Networks 5(1): 21-34, 2001.

21. Swan, K. Immediacy, social presence, and asynchronous discussion. In J. Bourne and J.C. Moore (Eds.), Elements of Quality Online Education, Volume 3. Needham, MA: The Sloan Consortium.

22. Picciano, A. G. Beyond student perceptions: Issues of interaction, presence, and performance in an online course. Journal of Asynchronous Learning Networks 6(1): 21-40, 2002.

23. Meyer, K. A. Evaluating online discussions: Four different frames of analysis. Journal of Asynchronous Learning Networks 8(2): 2004.

24. Meyer, K.A. The ebb and flow of online discussions: What Bloom can tell us about our students' conversations. Journal of Asynchronous Learning Networks 9(1): 2005.

25. Tiene, D. Online discussions: A survey of advantages and disadvantages compared to face-to-face discussions. Journal of Educational Multimedia and Hypermedia 9(4): 369-382, 2000.

26. Meyer, K. A. Face-to-face versus threaded discussions: The role of time and higher-order thinking. Journal of Asynchronous Learning Networks 7(3): 55-65, 2003.

27. An, Y., and T. Frick. Student perceptions of asynchronous computer-mediated communication in face-to-face classes. Journal of Computer-Mediated Communication 11(2): 2006. http://jcmc.indiana.edu/vol11/issue2/an.html.

28. Neuhauser, C. Learning style and effectiveness of online and face-to-face instruction. American Journal of Distance Education 16(2): 99-113, 2002.

29. Johnson, S. D., S. R. Aragon, N. Shaik and N. Palma-Rivas. Comparative analysis of learner satisfaction and learning outcomes in online and face-to-face learning environments. Journal of Interactive Learning Research 11(1): 29-49, 2000. 
30. Suthers, D., L. Girardeau and C. Hundhausen. Deictic roles of external representations in faceto-face and online collaboration. In B. Wasson, S. Ludvigsen and U. Hoppe (Eds.), Designing for Change in Networked Learning Environments, Proceedings of the International Conference on Computer Support for Collaborative Learning. Dordrecht: Kluwer Academic Publishers, 2003.

31. Schweizer, K., M. Paechter and B. Weidenmann. Blended learning as a strategy to improve collaborative task performance. Journal of Educational Media 28(2-3): 211-224.

32. Etzioni, A. and O. Etzioni. Communities: Virtual vs. real. Science Magazine 277(5324): 295, 1997.

33. Hammond, M. Learning through online discussion. Journal of Information Technology for Teacher Education 7(3): 331-346, 1998.

34. Allen, I. E. and J. Seaman. Entering the Mainstream: The Quality and Extent of Online Education in the United States, 2003 and 2004. Needham, MA: The Sloan Consortium, 2004. http://www.sloan-c.org/publications/survey/pdf/entering_mainstream.pdf.

35. Allen, I. E. and J. Seaman. Making the Grade: Online Education in the United States, 2006. Needham, MA: The Sloan Consortium, 2006. http://www.sloan-c.org/publications/survey /pdf/making_the_grade.pdf.

36. Allen, I. E. and J. Seaman. Why blended learning: A survey of practitioners In A. G. Picciano and C. D. Dziuban (Eds.), Blended Learning: Research Perspectives, 65-80. Needham, MA: The Sloan Consortium, 2007.

37. Picciano, A. G. Blended learning: Implications for growth and access. Journal of Asynchronous Learning Networks 10(3): 95-102, 2006.

38. Meyer, K. A. When topics are controversial: Is it better to discuss them face-to-face or online? Innovative Higher Education 31(3): 175-186, 2006.

39. Anderson, L. W. and D. R. Krathwohl (Eds). A Taxonomy for Learning, Teaching, and Assessing: A Revision of Bloom's Taxonomy of Educational Objectives. New York: Longman, 2001.

40. Maxwell, J. A. Qualitative Research Design: An Interactive Approach. Thousand Oaks, CA: Sage Publications, 1996.

41. Starenko, M., K. Vignare and J. Humbert. Enhancing student interaction and sustaining faculty instructional innovations through blended learning. In A. G. Picciano and C. D. Dziuban (Eds.), Blended Learning: Research Perspectives, 161-178. Needham, MA: The Sloan Consortium, 2007.

\section{ABOUT THE AUTHOR}

Dr. Meyer is currently associate professor of higher and adult education at The University of Memphis specializing in online learning and higher education. She is the author of Cost-efficiencies of Online Learning, a 2006 publication of the ASHE-ERIC Higher Education Report Series. For over three years, she was Director of Distance Learning and Technology for the University and Community College System of Nevada. Prior to this, she served over 8 years as Associate Director of Academic Affairs for the Higher Education Coordinating Board in the state of Washington and was responsible for technology planning and policy related to online learning. 